\title{
The Impacts of Edmodo App on EFL Students' Paragraph Writing
}

\author{
Yen Kieu Ngoc Lieu, Yen Hoang Phuong \\ Can Tho University, Vietnam
}

\begin{abstract}
The study aims to investigate the impacts of Edmodo on EFL students' paragraph writing. It also attempted to explore students' attitudes towards Edmodo application in a writing classroom. The study is a quasiexperimental study using a mixed research method with the participant of 70 tenth-grade learners in a high school. The participants were randomly divided in either the experimental or control group. For both groups, a pretest was run to check for group homogeneity and for later comparisons. Participants in the control group had a conventional class of writing whereas those in the experimental group learned writing lessons by integrating Edmodo application. The intervention lasted for eight weeks. Afterward, a posttest was given to the learners of the two groups to check if there is any improvement of their paragraph writing performance. Data collected from the pretest, posttest and questionnaire were analyzed using SPSS. The results of the interviews were transcribed and analyzed. The findings of the study indicated that the application of Edmodo significantly improved learners' paragraph writing performance. It is also found that students had positive attitudes toward the application of Edmodo in their writing classrooms.
\end{abstract}

Keywords: Edmodo app, paragraph writing, writing performance

\section{INTRODUCTION}

There is no doubt that English is one of the dominant languages in various fields, not only in economics and trade but also in education. There are four language skills learned by the learners namely: reading, listening, speaking and writing. As cited in Maryam Safdari (2021), Akkaya and Kirmiz (2013) stated that writing is an important language skill among the four language skills. Writing is also considered as the most important communication medium (Soliman, 2021). Through writing, students can express their thought, convey feelings and desires, and create new ideas. In terms of assessing languages, Maryam Safdari (2021) claimed that writing plays a vital role and is a criterion in measuring learner academic achievement. Therefore, it is necessary to understand and develop this skill. Nevertheless, Ma'azi and Janfeshan (2018) stated that writing is a complicated skill for both native and foreign students. Salma (2015, cited in Ma'azi \& Janfeshan, 2018) added that when English is regarded as a foreign language in EFL context, writing skill becomes the most challenging skill to the students. Therefore, nowadays, thanks to the rapid development of web technology and its effectiveness in diverse fields, many teachers are keen on applying technology in their lessons in order to improve students' language abilities (Al-naibi, AL-Jabari, \& Al Kalbani, 2018). Social networking platforms have been believed to be the most common instruments employed by teachers in teaching English. Because improving student's writing skills is a crucial task for language teachers, a lot of teachers use multimedia platforms and web tools to teach writing such as Learning Management System, Wikis, Social Networking Sites, Google Docs, Edmodo and many other tools. Specifically, one of these digital learning tools, Edmodo is said to be a very efficient and available online social networking website and a smartphone application in learning and teaching language skills, especially writing. (Hobsbawm, 2007; Monalisa \& Havid Ardi, 2013; Noviana et al., 2015; Charoenwet \& Christensen, 2016; Al-naibi et al., 2018; Ulfa et al., 2020; Soliman, 2021).

In Vietnam context, many students own smartphones and use them skilfully. They can access a number of websites and social networks they want to, especially Facebook. They can use English to text messages freely with so many abbreviation, wrong grammar and word choice. However, this kind of skill doesn't work in their English writing classrooms. Most of secondary students cannot gain the proficiency level as expected. As a result, students are experts of their digital tools, however, they cannot make use of them in learning. Moreover, in Circular 32/2020 of the Ministry of Education and Training on lower secondary school, upper secondary school, and multi-level school charter, students are now allowed to use their mobile phones for learning purposes in their classroom when they get their teacher's permission. In this light, beside the computer labs, the use of technology is exposed in the classroom, especially the use of mobile phones in teaching and learning. Thanks to the integration of information technology in education in Vietnam, a lot of educational websites, 


\section{DOI: $\underline{10.51386 / 25815946 / \text { ijsms-v4i6p118 }}$}

social learning platforms and mobile apps have been introduced and implemented as a virtual learning environment to facilitate the teaching and learning process. However, few studies were conducted on the fields of using social networking sites for language teaching and learning in foreign language learning in Vietnam, especially in high schools. Edmodo has not yet been used for enhancing the writing classroom experience because of the slow digital adoption in schools.

This study will be, therefore, conducted to find out the impact of Edmodo on EFL students' paragraph writing as well as the perception of the students toward the implementation of Edmodo in their writing classrooms. In relation to the research aims, the present study attempted to answer the two research questions below:

1. To what extent does the use of Edmodo app impact on students' paragraph writing?

2. What are students' perceptions toward the use of Edmodo app in their writing lessons?

\section{LITERATURE REVIEW}

\subsection{Writing skill and paragraph writing}

There are various ways to define writing. According to Sapkota( 2012, cited in Sari, 2018,p.70), "Writing is an activity of putting down the graphic symbols which has function to present a language in order to convey some meaning, thus, the reader can grasp the information". Writing was considered as the tool which enabled leaners to apply vocabulary and grammatical forms to conduct a wide range of tasks or activities related to the three skills: reading, listening and speaking. Also cited in Sari(2018), Nunan (2003) stated that beside inventing ideas to communicate, the activities of writing also include thinking about the ways to express and organize the ideas into statements and paragraphs clearly. In short, writing is the act of generating ideas and thoughts, summarizing, analyzing them in a reflective way. In terms of selecting written tasks for learners, writing was defined as a means and an end (Lombana, 2002).

Many researchers strongly agreed about the complexity of writing and its vital role in supporting other skills in learning and teaching of writing in both, the native language and the second/ foreign language (Harklau, 2002; Noviana et al., 2015; Rahmalia, 2016; Prananda, 2016; Rozalinda et al., 2020; Wali \& Madani, 2020; and Soliman, 2021). They added that writing enabled learners to pursue and fulfill academic purposes because most of the time university students had to write essays, reports, or assignments to meet the demand of institutional testing and assessing. Therefore, in order to achieve this skill, learners' thinking strategies and language competences are required (Saud, 2015). All in all, writing plays a crucial role in the success of learning and teaching any languages.

A paragraph was defined as "a combination of sentences, intended to explain, illustrate, or prove, or apply some truth; or to give a history of events during any definite portion of time, or in relation to any one subject of thought" by Angus (1862, p.401, cited in Duncan, 2007). Beyond the sentences, the paragraph was defined as the next division of discourse, as "a collection of sentences with unity of purpose" Bain(1866, p142, cited in Duncan, 2007). Similarly, according to Zemach and Rumisek(2005, p.11, cited in Muhtia and Suparno, 2019), a paragraph was " a group of sentences about a single topic". In other words, the writer's primary ideas or thoughts about the topic were illustrated by these sentences. A paragraph consisted of a topic sentence, supporting sentences and a concluding sentence.

Assessing writing is a very essential activity for teachers to get feedback about learners' understanding and achievement of writing competence (Cumming, 2002). In her part, she argued that in order to evaluate learners' writing ability in a foreign language, learners had been supported with a familiar context and form in most primary tests. Specifically, as cited in Duwila \& Khusaini (2019), Brown (2004) suggested that to see their progress, the paragraph as a main source of data will be analyzed for the five aspects of writing rubric: organization, vocabulary, grammar, mechanic, and content, which shaped up the framework for paragraph writing assessment used to design the pretest and the post-test used in the current study.

\subsection{Edmodo}

Edmodo was created by Nic Borg and JeffO'Hara (2008). According to Noviana et al. (2015), Edmodo was defined as a social network based school environment. Edmodo, one of learning platforms, is considered as the "Facebook for Education".(Hobsbawm, 2007, p.1). However, Haygood et al. (2012) stated that Edmodo is more private and safe because it supplies a free and secure learning platform for teachers, students, parents as 


\section{DOI: $\underline{10.51386 / 25815946 / \text { ijsms-v4i6p118 }}$}

well as schools. It is available at www.edmodo.com.(Noviana et al., 2015). In agreement with these statements, Habley (2011) emphasized that Edmodo was recognized as one of the top 25 websites promoting the qualities of innovation, creativity, active participation and collaboration by the American Association of School Librarians in 2011 as cited in Kandappan Balasubramaniana, Jaykumar Vb \& ASchool, 2014).

According to Gay \& Sofyan (2017), Edmodo is free, not commercializing, which means that users aren't annoyed by so many disturbed commercials popping up during their study. It enables students to find the information of the class they are attending easily. In terms of connection and collaboration in a virtual class, Edmodo supports teachers and students with a simple way to communicate effectively because Edmodo facilities them in sharing content, submitting homework, assignments and quizzes, receiving their teacher's feedback notes as well as voting on polls. Jarc (2010, cited in Kandappan Balasubramaniana, Jaykumar Vb \& ASchool, 2014).

Although Edmodo provides considerable benefits, it also comes with its own challenges when implementing it in the classroom. The participants in Mali's study(2014) also addressed a few drawbacks. If a student does not have access to computer and Internet, or a mobile device they would not be able to use the tool. Not all areas have good internet connection and not all students have a computer at home. Moreover, the findings of the study found that the students could not distribute an assignment and do task by their Edmodo mobile application. That forgetting the Edmodo password is another downside which students often faced in learning on Edmodo.

\subsection{Learner attitudes toward Edmodo in teaching writing}

In literature, several definitions of attitudes can be found, and these descriptions are offered basing on the perspectives of attitudes that the research look at. Some studies were conducted to estimate attitudes from affective and cognitive viewpoint.(van Harreveld et al., 2015; and Ozag \& Duguma, 2004). As cited in Eagly et al. (1999), Eagly and Chaiken (1993) defined that attitude is a psychological phenomenon which is conveyed by evaluating a particular entity with some levels of likes or dislikes. In other words, attitudes are subjective and personal attributes and difficult to measure. They also suggested "attitudes" with three fundamental elements: affective, behavioural and cognitive.

Recently, there were a few studies conducted to explore attitudes on the use of Edmodo. Thongmak (2013) using Thailand case mixed the technology acceptance model with instructor characteristics, students characteristics, and student's past behaviour to examine the effectiveness of acceptance constructs ( perceived usefulness and perceived ease of use), instructor-related construct (instructor characteristics), and student-related constructs (student characteristics and past behaviour) on Edmodo adoption. Mali (2014) conducted a study aiming at investigating opinions of 21 Indonesian undergraduates about the use of Edmodo. The data gave the evidence that these students had a positive response to the use of Edmodo. In addition, Al-Said (2015) attempted to investigate the students' perceptions degrees of Edmodo as well as to determine the challenges of them at Taibah University. Ma'azi \& Janfeshan (2018) conducted an action research to measure the effectiveness of Edmodo social learning network on students' writing skill in EFL classrooms in Iran. Also, the results also showed that students perceived favourably the application of Edmodo in the classroom.

Furthermore, Duwila \& Khusaini (2019) aimed at investigating the integration of Genres- based Approaches and Edmodo whether students were helped by this teaching strategy. Maryam Safdari (2021) evaluated the contribution of Edmodo to Iranian EFL learners' writing accuracy through experimental research design. The results of content analysis stated that learners held positive attitude towards the implication of Edmodo. Another study was conducted by Soliman (2021). It was a one-group quasi-experimental design. The research aimed at investigating the impact of Edmodo on improving secondary stage students' writing performance skills.

\section{METHODOLOGY}

In attempt to find out the answers for the two research questions based on the research context, the mixed method was employed. As each type has its own strengths and limitations (Creswell, 2013), it is better to integrate two methods to overcome the weaknesses of each. The study utilized a pre-test/post-test experimental and control design in an attempt to evaluate the use of Edmodo app in EFL students' paragraph writing. A questionnaire designed with a five - point Likert scale was used to collect quantitative data on the grade 10 students' reaction towards the application of Edmodo app in their writing classroom. Afterward, the qualitative 


\section{DOI: $\underline{10.51386 / 25815946 / \text { ijsms-v4i6p118 }}$}

method, with a semi-structured interview, was employed to gain more insights into the grade 10 students' perceptions towards the application of Edmodo app in their writing classroom.

The study is conducted at a high school in a province in Vietnam with 70 grade 10th students. These students were randomly selected from 2 classes and randomly assigned to 2 groups: an experimental group (n= $35)$ and a control group $(n=35)$. The experimental group included 35 students, 8 males and 27 females. The control group consisted of 19 males and 16 females. Students' age ranges from 15 to 16 .

The study consisted of 3 phases. Phase 1 lasted two weeks before the intervention. Phase 2 was the administration of the intervention with the duration of 8 weeks. Phase 3 was conducted after the treatment and lasted 3 weeks.

Phase 1 was aimed at preparing for the participant enrollment and the instruments of the study. In Phase 2, the intervention was administered during 8 weeks. The experimental group was instructed to use Edmodo so as to learn the process of writing in class. The process of writing was taught in class to the experimental group followed by using Edmodo as a follow-up activity in a blended learning environment, whereas the control group followed the traditional method of teaching writing in studying the same material without using Edmodo.

In Phase 3, after the intervention, the post-test was administered on the control group and the experimental one without any notification. The procedure to administer the posttest and to grade the participants' writing was like that of the pretest. Afterward, the official questionnaire was sent to 35 participants who involved in the treatment. Then, the data of the questionnaire were gathered to analyze by the software SPSS 26.0. After collecting the quantitative data from the questionnaire, a semi-structured interview, including 7 questions related to EFL students' background information, expectations, satisfaction levels, and suggestions was employed. Appointments between the researcher and the interviewees were made after the researcher had piloted the interview questions and finished collecting data from the questionnaire. The one-on-one interviews were conducted with 06 students, who have participated in the treatment. The interviews were recorded then transcribed for data analysis. However, due to the Covid-19 pandemic has been still happening complicatedly, the interviews was conducted online via Zoom.

\section{FINDINGS}

After analysing the data from the writing tests, questionnaire and interviews, an improvement of EFL students' paragraph writing performance through the use of Edmodo and EFL students' high positive attitudes towards using Edmodo app in learning paragraph writing were found.

\subsection{Participants' paragraph writing subskills within the two groups before and after the intervention}

The General Linear Model Test was run to identify students' changes in paragraph writing subskills (the five aspects of writing rubric, which the researcher used to grade the participants' writings, mentioned in assessing writing in Chapter 2). Firstly, the result of the control group's pre-test and post-test was gathered and analyzed. With $\mathrm{p}=.000$, it is confident enough to conclude that the pre-test's and the post-test's mean scores are significantly different. After that, a Descriptive Statistic Test was conducted to verify the mean score of each subskill in each test. It can be concluded that students' paragraph writing subskills were improved.

Table 4.1a: Mean difference of students' paragraph writing subskills within the control group

\begin{tabular}{llllllll}
\hline Group & Subskills & Tests & N & Minimum & Maximum & Mean & SD \\
\hline Control & Organization & Pretest & 35 & 1.2 & 1.9 & 1.663 & .1536 \\
& Costtest & 35 & 1.4 & 2.0 & 1.737 & .1437 \\
& Content & Pretest & 35 & 1.4 & 1.9 & 1.691 & .1380 \\
& Posttest & 35 & 1.4 & 2.0 & 1.714 & .1611 \\
& & & & & & \\
& & & & & 1.8 & 1.649 & .1292 \\
& Vocabulary & Pretest & 35 & 1.3 & 1.9 & 1.654 & .1221 \\
& Grammar & Posttest & 35 & 1.3 & 1.9 & 1.600 & .2425 \\
& Pretest & 35 & 1.1 & 1.8 & 1.646 & .1146 \\
& Mechanics & Posttest & 35 & 1.4 & 1.9 & 1.600 & .2425 \\
& & Pretest & 35 & 1.1 & 2.0 & 1.640 & .2354 \\
\hline
\end{tabular}




\section{DOI: $\underline{10.51386 / 25815946 / \text { ijsms-v4i6p118 }}$}

Volume: 4 Issue: 6

November to December 2021

https://www.ijsmsjournal.org

Table 4.1b: Mean difference of students' paragraph writing subskills within the experimental group

\begin{tabular}{|c|c|c|c|c|c|c|c|}
\hline Group & Subskills & Tests & $\mathbf{N}$ & Minimum & Maximum & Mean & SD \\
\hline \multirow[t]{10}{*}{ Experimental } & Organization & Pretest & 35 & 1.3 & 1.9 & 1.689 & .1491 \\
\hline & & Posttest & 35 & 1.5 & 2.0 & 1.834 & .1327 \\
\hline & Content & Pretest & 35 & 1.4 & 1.9 & 1.729 & .1178 \\
\hline & & Posttest & 35 & 1.5 & 2.0 & 1.857 & .1220 \\
\hline & Vocabulary & Pretest & 35 & 1.3 & 1.9 & 1.643 & .1220 \\
\hline & & Posttest & 35 & 1.5 & 2.0 & 1.829 & .1017 \\
\hline & Grammar & Pretest & 35 & 1.4 & 1.9 & 1.643 & .1378 \\
\hline & & Posttest & 35 & 1.6 & 2.0 & 1.829 & .1073 \\
\hline & Mechanics & Pretest & 35 & 1.0 & 2.0 & 1.666 & .2520 \\
\hline & & Posttest & 35 & 1.3 & 2.0 & 1.837 & .1682 \\
\hline
\end{tabular}

As can be seen in Table 4.1b, the mean score of the subskills in post-test was higher than those of the pre-test. It can be concluded that students' subskills were all improved. The results also showed that student's grammar and vocabulary improved remarkably.

\subsection{Participants' paragraph writing subskills between the two groups before and after the intervention}

\subsubsection{Participants' paragraph writing subskills between the two groups before the intervention}

To evaluate students' paragraph writing subskills between the two groups before and after the intervention, the Descriptive Statistic Test, the Independent Sample T Test and the General Linear Model Test were carried out. First, the results of the Descriptive Statistic Test were presented in Table 4.2.1 below. Results showed that before the treatment, two groups of students' writing subskills were the same (control group- M=1.64, experimental group- $\mathrm{M}=1.67$ ).

Table 4.2.1: Mean difference of students' paragraph writing subskills between the two groups before the treatment

\begin{tabular}{|c|c|c|c|c|c|c|c|}
\hline Test & Subskills & Groups & $\mathbf{N}$ & Minimum & Maximum & Mean & SD \\
\hline \multirow[t]{12}{*}{ Pretest } & Organization & Control & 35 & 1.2 & 1.9 & 1.663 & .1536 \\
\hline & & Experimental & 35 & 1.3 & 1.9 & 1.689 & .1491 \\
\hline & Content & Control & 35 & 1.4 & 1.9 & 1.691 & .1380 \\
\hline & & Experimental & 35 & 1.4 & 1.9 & 1.729 & .1178 \\
\hline & Vocabulary & Control & 35 & 1.3 & 1.8 & 1.649 & .1292 \\
\hline & & Experimental & 35 & 1.3 & 1.9 & 1.643 & .1220 \\
\hline & Grammar & Control & 35 & 1.1 & 1.9 & 1.600 & .2425 \\
\hline & & Experimental & 35 & 1.4 & 1.9 & 1.643 & .1378 \\
\hline & Mechanics & Control & 35 & 1.1 & 1.9 & 1.600 & .2425 \\
\hline & & Experimental & 35 & 1.0 & 2.0 & 1.666 & .2520 \\
\hline & Total & Control & 35 & 1.30 & 1.84 & 1.6446 & .13258 \\
\hline & & Experimental & 35 & 1.32 & 1.86 & 1.6737 & .12535 \\
\hline
\end{tabular}

\subsubsection{Participants' paragraph writing subskills between the two groups after the intervention}

The results from Table 4.2.2 also revealed that after the intervention the students' paragraph writing subskills between the two groups was different. The mean scores of the subskills in the post-test of the two groups were highly increased ( $\mathrm{M}=1.7$ - for the control group, and $\mathrm{M}=1.83$ - for the experimental group).

Table 4.2.2: Mean difference of students' paragraph writing subskills between the two groups after the treatment

\begin{tabular}{llllllll}
\hline Test & Subskills & Groups & N & Minimum & Maximum & Mean & SD \\
\hline Posttest & Organization & Control & 35 & 1.4 & 2.0 & 1.737 & .1437 \\
& & Experimental & 35 & 1.5 & 2.0 & 1.834 & .1327 \\
& \multirow{3}{*}{ Content } & Control & 35 & 1.4 & 2.0 & 1.714 & .1611 \\
& & Experimental & 35 & 1.5 & 2.0 & 1.857 & .1220 \\
\hline
\end{tabular}




\section{DOI: $\underline{10.51386 / 25815946 / \text { ijsms-v4i6p118 }}$}

Volume: 4 Issue: $6 \quad$ November to December 2021

https://www.ijsmsjournal.org

\begin{tabular}{|c|c|c|c|c|c|c|}
\hline \multirow[t]{2}{*}{ Vocabulary } & Control & 35 & 1.3 & 1.9 & 1.654 & .1221 \\
\hline & Experimental & 35 & 1.5 & 2.0 & 1.829 & .1017 \\
\hline \multirow[t]{2}{*}{ Grammar } & Control & 35 & 1.4 & 1.8 & 1.646 & .1146 \\
\hline & Experimental & 35 & 1.6 & 2.0 & 1.829 & .1073 \\
\hline \multirow[t]{2}{*}{ Mechanics } & Control & 35 & 1.0 & 2.0 & 1.640 & .2354 \\
\hline & Experimental & 35 & 1.3 & 2.0 & 1.837 & .1682 \\
\hline \multirow[t]{2}{*}{ Total } & Control & 35 & 1.36 & 1.88 & 1.6703 & .13154 \\
\hline & Experimental & 35 & 1.50 & 1.96 & 1.8371 & .10072 \\
\hline
\end{tabular}

The results above lead to the conclusion that participants who use Edmodo app for their paragraph learning improved their paragraph writing subskills more remarkably than the students leaning with the traditional method.

\subsection{Participants' paragraph writing performance within the two groups before and after the intervention}

The General Linear Model Test was run to identify students' changes in paragraph writing performance. Firstly, the result of the control group's pre-test and post-test was gathered and analyzed. With $\mathrm{p}=.000$, it is confident enough to conclude that the pre-test's and the post-test's mean scores are significantly different. After that, a Descriptive Statistic Test was conducted to verify the mean score of each test. The result was illustrated in Table 4.3a.

Table 4.3a: Mean difference of students' paragraph writing performance within the control group

\begin{tabular}{lcrrrrr} 
& Tests & N & Minimum & Maximum & $\begin{array}{r}\text { Std. } \\
\text { Mean }\end{array}$ & Deviation \\
\hline Control & Pretest & 35 & 6.5 & 9.2 & 8.223 & .6629 \\
Group & Posttest & 35 & 6.8 & 9.4 & 8.380 & .6516 \\
\hline
\end{tabular}

From Table 4.3a, the result showed the difference of means in the pre-test $(\mathrm{M}=8.22, \mathrm{SD}=.662)$ and post-test $(\mathrm{M}=8.38, \mathrm{SD}=.651)$. The mean score of the post-test was higher than that of the pre-test. It can be concluded that participants' paragraph writing performance was improved.

Another General Linear Model Test was carried out to identify the difference mean scores of the experimental group's pre-test and post-test. The result $(\mathrm{p}=.000)$ reveals that the pre-test's and post-test's mean scores are significantly different. After that, a Descriptive Statistic Test was conducted to verify the mean score of each test. The result was illustrated in Table $4.3 \mathrm{~b}$.

Table 4.3b: Mean difference of students' paragraph writing performance within the experimental group

\begin{tabular}{llrrrrr}
\hline \multirow{2}{*}{ Experimental Group } & Tests & $\mathbf{N}$ & Minimum & Maximum & Mean & Std. Deviation \\
& Pretest & 35 & 6.6 & 9.3 & 8.369 & .6267 \\
& Posttest & 35 & 7.5 & 9.8 & 9.189 & .5046 \\
\hline
\end{tabular}

The result from Table $4.3 \mathrm{~b}$ showed the mean difference of students' paragraph writing performance within experimental group. The mean score of the pre-test $(\mathrm{M}=8.36, \mathrm{SD}=.626)$ was different from that of the post-test $(\mathrm{M}=9.18, \mathrm{SD}=.504)$. The result shows that the mean of the post-test was higher than that of the pre-test. In other words, the paragraph writing performance of the experimental group was remarkably improved after the intervention.

\subsection{Participants' paragraph writing performance between the two groups before and after the intervention}

To evaluate students' paragraph writing performance between the two groups before and after the intervention, the Descriptive Statistic Test, the Independent Sample T Test and the General Linear Model Test were carried out. First, the results of the Descriptive Statistic Test were presented in Table 4.4 below.

\subsubsection{Participants' paragraph writing performance between the two groups before the intervention}

Before the intervention, in the pre-test, the mean score of the experimental group $(M=8.36)$ was a little bit higher than the mean score of the control group $(M=8.22)$. To check whether there was a significant difference in the students' paragraph writing performance in the pre-test between the control group and the experimental group, an Independent Sample T Test was run. The results showed that the difference in the 


\section{DOI: $\underline{10.51386 / 25815946 / \mathrm{ijsms}-\mathrm{v} 4 \mathrm{i} 6 \mathrm{p} 118}$}

Volume: 4 Issue: 6

November to December 2021

https://www.ijsmsjournal.org

students' paragraph writing performance in the pretest was not significant. The two groups were distributed homogeneously before the intervention.

Table 4.4.1: Students' paragraph writing performance between the two groups

\begin{tabular}{llrrrrr} 
Tests & Groups & N & Minimum & Maximum & Mean & SD \\
\hline Pre-test & Control & 35 & 6.5 & 9.2 & 8.223 & .6629 \\
& Experimental & 35 & 6.6 & 9.3 & 8.369 & .6267 \\
Posttest & Control & 35 & 6.8 & 9.4 & 8.380 & .6516 \\
& Experimental & 35 & 7.5 & 9.8 & 9.189 & .5046 \\
\hline
\end{tabular}

\subsubsection{Participants' paragraph writing performance between the two groups after the intervention}

The results from Table 4.4 also revealed that after the intervention the students' paragraph writing performance between the two groups was different. The mean scores of the post-test of the two groups were highly increased ( $M=8.38$ - for the control group, and $M=9.18$ - for the experimental group).

It can be seen from the table that there was a small gap between the two group's paragraph writing performance at the pre-test (control group $\mathrm{M}=8.22$, experimental group $\mathrm{M}=8.36$ ). After the intervention, the paragraph writing performance of the two groups improved. However, in the post- test, the mean score of the students' paragraph writing performance of the control group was $\mathrm{M}=8.38$ while that of the experimental group was $\mathrm{M}=9.18$ ). The results above lead to the conclusion that participants who use Edmodo app for their paragraph learning improved their paragraph writing performance more remarkably than the students leaning with the traditional method.

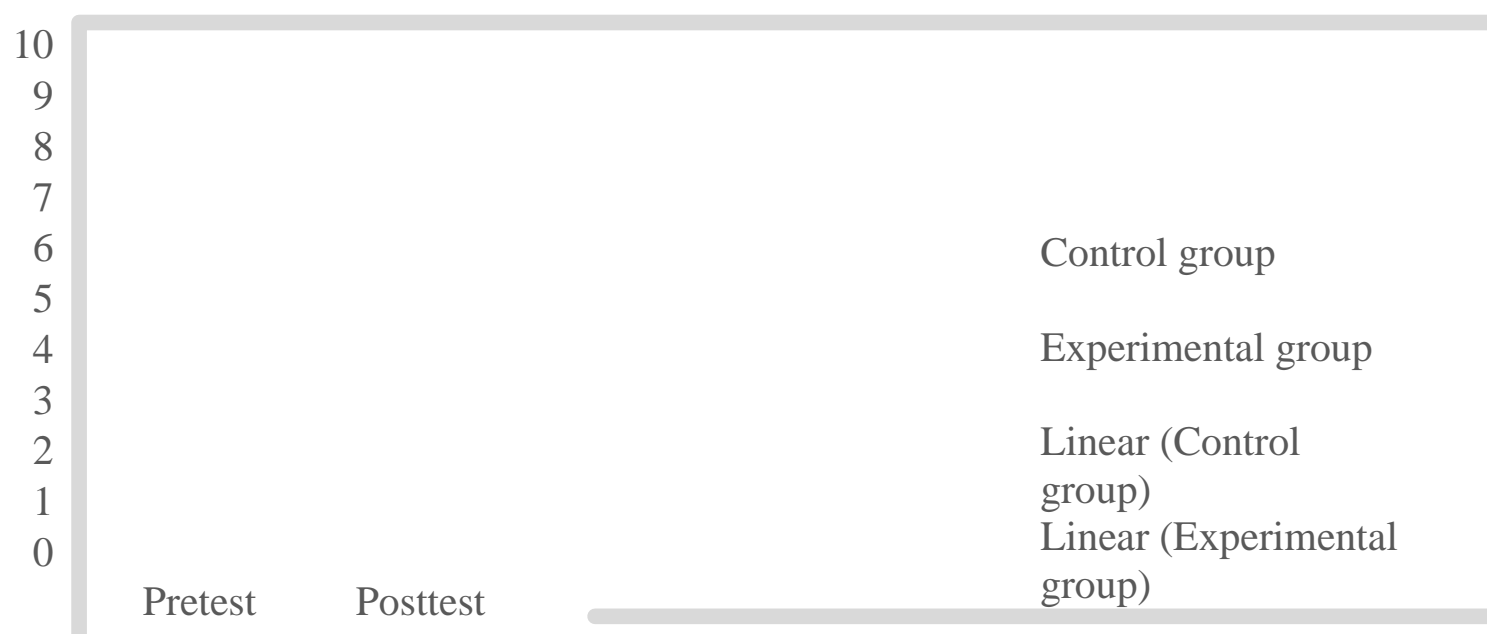

\subsection{Students' attitude towards using the Edmodo app in their paragraph writing learning in the experimental group}

With the aim of exploring students' attitude towards using the Edmodo app in their paragraph writing learning, the questionnaire was delivered to 35 students in the experimental group. The responses gathered from the questionnaires were entered to SPSS version 26 for quantitative data analysis. Then, a Scale test was administered in order to check the reliability of the instrument. As shown in Table 4.5, the questionnaire was highly reliable (Cronbach's Alpha $=.947)$ to collect data for the study.

Table 4.5 The reliability of the pilot questionnaire and the official questionnaire

\begin{tabular}{lrrr}
\hline & Cronbach's Alpha & No. of items & No. of respondents \\
Pilot Questionnaire & .935 & 36 & 32 \\
Official Questionnaire & .947 & 36 & 35 \\
\hline
\end{tabular}


DOI: $\underline{10.51386 / 25815946 / \text { ijsms-v4i6p118 }}$

Volume: 4 Issue: 6

November to December 2021

https://www.ijsmsjournal.org

\subsubsection{Students' time of using Edmodo app in learning their paragraph writing outside classrooms}

A Frequency Statistic Test was run to measure students' time of using Edmodo app in learning paragraph writing outside of the class. It can be inferred that the participants worked with the Edmodo app in practicing their paragraph writing at an average time per week.

Table 4.5.1 Time students learning paragraph writing outside of the class

\begin{tabular}{lrrrr}
\hline & Frequency & Percent & Valid Percent & $\begin{array}{r}\text { Cumulative } \\
\text { Percent }\end{array}$ \\
\hline $\begin{array}{l}\text { Less than 20 minutes each } \\
\text { week }\end{array}$ & 9 & 6.7 & 25.7 & 25.7 \\
$\begin{array}{l}\text { Between 20-40 minutes } \\
\text { each week }\end{array}$ & 20 & 14.8 & 57.1 & 82.9 \\
$\begin{array}{l}\text { Between 40-60 minutes } \\
\text { each week }\end{array}$ & 6 & 4.4 & 17.1 & 100.0 \\
Total & 35 & 25.9 & 100.0 & \\
\hline
\end{tabular}

\subsubsection{Students' frequent use of each function of Edmodo app}

A Descriptive Statistic Test was run to check the overall mean score of students' frequent use of Edmodo app in their paragraph writing. Regarding to Oxford's (1990) scale, the overall mean score at a medium level (M= 2.72, Table 4.5.2a). It can be seen that among the six functions, the Assignment function $(\mathrm{M}=3.54, \mathrm{SD}=.980)$ was the most frequent used function.

Table 4.5.2a: The mean score of students' frequent use of Edmodo app

\begin{tabular}{|c|c|c|c|c|c|}
\hline & $\mathrm{N}$ & Minimum & Maximum & Mean & Std. Deviation \\
\hline M-Frequency & 35 & 1.50 & 4.00 & 2.7238 & .70704 \\
\hline \multicolumn{6}{|c|}{ Table 4.5.2b: The mean score of students' frequent use of each function of Edmodo app } \\
\hline & $\mathrm{N}$ & Minimum & Maximum & Mean & SD \\
\hline ASSIGNMENT function & 35 & 2 & 5 & 3.54 & .980 \\
\hline POST function & 35 & 1 & 5 & 3.09 & 1.222 \\
\hline QUIZZES function & 35 & 1 & 5 & 2.69 & 1.022 \\
\hline LIBRARY function & 35 & 1 & 4 & 2.51 & 1.040 \\
\hline NOTE function & 35 & 1 & 4 & 2.49 & 1.011 \\
\hline PLANNER function & 35 & 1 & 4 & 2.03 & .954 \\
\hline
\end{tabular}

\subsubsection{Students' perception of the importance of each function}

A Descriptive Statistic Test was carried out to examine the total mean score of students' perception of the importance of Edmodo app.

Table 4.5.3a: The mean score of students' perception of the importance of Edmodo app

\begin{tabular}{lrrrrr}
\hline & $\mathrm{N}$ & Minimum & Maximum & Mean & Std. Deviation \\
\hline M-Importance & 35 & 2.17 & 4.83 & 3.8714 & .59968 \\
\hline
\end{tabular}

Table 4.5.3a reveals that the mean score of students' perception of the importance of Edmodo app $(\mathrm{M}=3.87, \mathrm{SD}=.59)$ is higher than the medium scale 3.5. The sample mean $(\mathrm{M}=3.87, \mathrm{SD}=.59)$ was significantly different from 3.5 $(\mathrm{t}=3.664, \mathrm{df}=34, \mathrm{p}=.00)$. It means that students recognized clearly the importance of Edmodo app in their paragraph writing. In addition, SD scores of all items are smaller than 1 . It can be assumed that the variations in students' perceptions of the importance of Edmodo functions are not high.

Table 4.5.3b: The mean score of students' perception of the importance of each function

\begin{tabular}{lrrrrr}
\hline & $\mathrm{N}$ & Minimum & Maximum & Mean & SD \\
\hline ASSIGNMENT function. & 35 & 3 & 5 & 4.40 & .695 \\
PLANNER function & 35 & 2 & 5 & 4.06 & .906 \\
QUIZZES function & 35 & 1 & 5 & 4.00 & .907 \\
NOTE function & 35 & 2 & 5 & 3.66 & .998 \\
POST function & 35 & 1 & 5 & 3.63 & .877
\end{tabular}




\section{DOI: $\underline{10.51386 / 25815946 / \text { ijsms-v4i6p118 }}$}

Volume: 4 Issue: 6

November to December 2021

https://www.ijsmsjournal.org

\begin{tabular}{llllll} 
LIBRARY function & 35 & 1 & 5 & 3.49 & .951 \\
\hline
\end{tabular}

\subsubsection{Students' preference of each function}

A Descriptive Statistic Test was run to examine the total mean score of students' preference for Edmodo app. From Table 4.5.4 a, the mean score of students' preference for Edmodo app $(\mathrm{M}=3.63, \mathrm{SD}=.58)$ is higher than the medium scale 3.5. The sample mean $(\mathrm{M}=3.63, \mathrm{SD}=.58)$ was significantly different from $3.5(\mathrm{t}=1.396$, $\mathrm{df}=34, \mathrm{p}=.17)$. It means that students enjoyed using Edmodo app in their paragraph writing.

Table 4.5.4a: The mean score of students' preference for Edmodo app

\begin{tabular}{rrrrrr}
\hline & $\mathrm{N}$ & Minimum & Maximum & Mean & Std. Deviation \\
M-Interest & 35 & 2.67 & 4.83 & 3.6381 & .58506 \\
\hline
\end{tabular}

Table 4.5.4b: The mean score of students' preference for each function of Edmodo app

\begin{tabular}{lccrrr}
\hline & N & Minimum & Maximum & $\begin{array}{r}\text { Std. } \\
\text { Mean }\end{array}$ & $\begin{array}{r}\text { Deviation } \\
\hline \text { ASSIGNMENT function. }\end{array}$ \\
LIBRARY function & 35 & 3 & 5 & 5 & .747 \\
POST function & 35 & 2 & 5 & 3.71 & .825 \\
QUIZZES function & 35 & 1 & 5.69 & .932 \\
PLANNER function & 35 & 2 & 5 & 3.66 & .873 \\
NOTE function & 35 & 2 & 5.40 & .881 \\
\hline
\end{tabular}

\subsubsection{Students' attitude towards using Edmodo app in their learning paragraph writing}

A Descriptive Statistic Test was carried out to examine the total mean score of students' attitude towards using Edmodo in learning paragraph writing. From table 4.5.5a, the mean score of students' attitude towards using Edmodo in learning paragraph writing $(\mathrm{M}=4.10, \mathrm{SD}=.57)$ is at a high level. The results revealed that participants have positive attitudes towards using Edmodo in learning paragraph writing.

Table 4.5.5a: The overall mean score of students' attitude towards using Edmodo in learning paragraph writing

\begin{tabular}{lrrrrr} 
& $\mathrm{N}$ & Minimum & Maximum & Mean & Std. Deviation \\
\hline M-Attitude & 35 & 3.00 & 5.00 & 4.1063 & .57631 \\
\hline
\end{tabular}

Table 4.5.5b: Participants' Levels of Attitude

\begin{tabular}{ll}
\hline Scale value & Rank \\
\hline $1.00-1.80$ & Very Negative \\
$1.81-2.61$ & Negative \\
$2.62-3.40$ & Moderate \\
$3.41-4.21$ & Positive \\
$4.22-5.00$ & Very Positive \\
\hline
\end{tabular}

\subsubsection{Students' cognitive attitude towards using Edmodo app in their learning of paragraph writing}

A Descriptive Statistic Test was run to examine the mean score of students' cognitive attitude towards using Edmodo in learning paragraph writing. From Table 4.5.5.1a, the mean score of students' cognitive attitude towards using Edmodo in learning paragraph writing $(\mathrm{M}=4.13, \mathrm{SD}=.58)$ is at a high level. A One Sample T-Test was run on students' cognitive attitude towards using Edmodo in learning paragraph writing to examine whether the mean was significantly different from the scale 3.5 of the positive attitudes. The sample mean $(M=4.13$, $\mathrm{SD}=.58)$ was significantly different from $3.5(\mathrm{t}=6.441, \mathrm{df}=34, \mathrm{p}=.00)$.

Table 4.5.5.1a: The mean score of students' attitude towards using Edmodo in learning paragraph writing

\begin{tabular}{lrrrrr} 
& $\mathrm{N}$ & Minimum & Maximum & Mean & SD \\
Mean-Cognitive & 35 & 3.00 & 5.00 & 4.1397 & .58754 \\
\hline
\end{tabular}

Table 4.5.5.1b: The detailed mean score of students' cognitive attitude towards using Edmodo in learning paragraph writing

\begin{tabular}{|c|c|c|c|}
\hline No & Mean & SD & Rank \\
\hline $\begin{array}{l}\text { 27. Practicing writing paragraph on Edmodo app, I can get useful comments } 35 \\
\text { on my writing. }\end{array}$ & 4.37 & .690 & Very Positive \\
\hline $\begin{array}{l}\text { 33. The vocabulary exercises on Edmodo app help me enlarge my vocabulary } 35 \\
\text { about the topic. }\end{array}$ & 4.31 & .631 & Very Positive \\
\hline
\end{tabular}




\section{DOI: $\underline{10.51386 / 25815946 / \text { ijsms-v4i6p118 }}$}

Volume: 4 Issue: 6

November to December 2021

https://www.ijsmsjournal.org

$\begin{array}{lllll}\text { 30. The grammar exercises on Edmodo app make me aware of writing } & 35 & 4.29 & .750 & \text { Very Positive } \\ \text { "correct" sentences. } & & & & \\ \text { 28. I was able to have a wide range of writing activities using Edmodo app. } & 35 & 4.26 & .741 & \text { Very Positive } \\ \text { 26. The activity tabs on Edmodo are clearly displayed. } & 35 & 4.20 & .759 & \text { Positive } \\ \text { 21. I think Edmodo app is an easy tool to use for English paragraph writing. } & 35 & 4.20 & .833 & \text { Positive } \\ \text { 29. I have more knowledge about the topic through idea exploring activities } & 35 & 4.11 & .676 & \text { Positive } \\ \text { using Edmodo app. } & 35 & 4.06 & .765 & \text { Positive } \\ \text { 19. I think Edmodo app is clear and understandable. } & & & \\ \text { 24. When I find a discussion posted on Forum, I want to reply it right away. } & 35 & 3.46 & .886 & \text { Positive }\end{array}$

Results in Table 4.5.5.1b revealed that participants perceived the usefulness and the ease of use of Edmodo in learning paragraph writing. Mean scores of four elements (item 27-M=4.37, SD=.690; item 28$\mathrm{M}=4.26 \mathrm{SD}=.741$; item 30- $\mathrm{M}=428, \mathrm{SD}=.750$; item 33- $\mathrm{M}=4.31, \mathrm{SD}=.631$ ) related to exercises and activities on Edmodo were very positive. It can be seen that the student strongly agreed that they got useful comments on their writing when practicing writing paragraph on Edmodo app with a lot of activities. Beside the knowledge about the topic, many participants had an agreement that Edmodo supported them with the grammar and vocabulary exercises which help students raise awareness of writing correct sentences and enrich their vocabulary, especially the way to use word properly and sufficiently. It can be concluded that the students perceived the usefulness and the ease of use of Edmodo app positively.

\subsubsection{Students' affective and behavioral attitude towards using Edmodo app in their learning of paragraph writing}

In order to investigate students' affective and behavioral attitude towards using Edmodo app in their learning paragraph writing, Descriptive Statistic Test was conducted to compute the mean score of students' affective and behavioral attitude towards using Edmodo in learning paragraph writing. As shown in table 4.5.5.2a, the mean score of students' affective and behavioral attitude towards using Edmodo in learning paragraph writing $(\mathrm{M}=4.07, \mathrm{SD}=.59)$ is at a high level. A One Sample T-Test was run on students' affective and behavioral attitude towards using Edmodo in learning paragraph writing to examine whether the mean was significantly different from the scale 3.5. The sample mean $(\mathrm{M}=4.07, \mathrm{SD}=.59)$ was significantly different from $3.5(\mathrm{t}=5.695, \mathrm{df}=34, \mathrm{p}=.00)$.

Table 4.5.5.2a: The mean score of students' attitude towards using Edmodo in learning paragraph writing

\begin{tabular}{lrrrrr}
\hline & $\mathrm{N}$ & Minimum & Maximum & Mean & Std. Deviation \\
\hline Mean-Affective\& Behavioral & 35 & 3.00 & 5.00 & 4.0730 & .59527 \\
\hline
\end{tabular}

Table 4.5.5.2b: The detailed mean score of students' affective and behavioral attitude towards using Edmodo in learning paragraph writing

\begin{tabular}{lccc}
\hline No & N & Mean & SD Rank \\
\hline $\begin{array}{l}\text { 31. Edmodo app motivates me to do more writing assignments } \\
\text { outside the classroom. }\end{array}$ & 35 & 4.31 & .758 Very Positive \\
36. If I am offered, I intend to write English with Edmodo app. & 35 & 4.29 & .750 Very Positive \\
$\begin{array}{l}\text { 25. I think Edmodo app was useful in my class. } \\
\text { 20. I like Edmodo app because I can access it to practice writing on } \\
\text { my own devices. }\end{array}$ & 35 & 4.20 & .797 Positive \\
32. Edmodo app increased my passion in writing paragraph. & 3.17 & .707 Positive \\
35. I intend to practice writing with Edmodo app in the future. & 35 & 4.09 & .702 Positive \\
34. Writing on forums makes me more confident in my writing. & 35 & 3.97 & .747 Positive \\
$\begin{array}{l}\text { 22. Forums on Edmodo app help me share my writing with my } \\
\text { friends. }\end{array}$ & 35 & 3.71 & .710 Positive \\
23. I enjoy studying writing with Edmodo app. & 35 & 3.89 & .796 Positive
\end{tabular}

Results in Table 4.5.5.2b showed the detailed mean score of students' affective and behavioral attitude towards using Edmodo in learning paragraph writing. It can be seen that many participants had positive attitudes towards the use of Edmodo in their paragraph writing learning (item 20-M=4.17, SD=.707, item 23- M=3.89, $\mathrm{SD}=.796$, item $25-\mathrm{M}=4.20, \mathrm{SD}=.797$ ). In other words, data reveal that participants have positive attitudes towards using Edmodo in learning paragraph writing. It can be assumed that participants have positive belief, factual knowledge, and future intention in using the app respectively. 


\section{DOI: $\underline{10.51386 / 25815946 / \text { ijsms-v4i6p118 }}$}

\subsection{Differences in students' attitudes towards using Edmodo in learning paragraph writing}

An Independent Sample T Test was run to check the differences in students' attitudes towards using Edmodo in learning paragraph writing between male and female participants in the experimental group. Table 4.6 showed the mean score of two groups of learners' attitudes. As can be seen from the table, both males and females had positive attitudes towards using Edmodo in learning paragraph writing (male $\mathrm{M}=4.10, \mathrm{SD}=.59$; female $=4.10, \mathrm{SD}=.53$ ). The results reported that there was no difference in participants' attitudes towards using Edmodo in learning paragraph writing between male and female students $(\mathrm{p}=.607>0.05)$.

Table 4.6: An Independent- Sample $\mathrm{T}$ Test on students' attitudes towards using Edmodo in learning paragraph writing

\begin{tabular}{llrrrr} 
& Gender & $\mathrm{N}$ & Mean & Std. Deviation & Std. Error Mean \\
\hline M-Attitude & Female & 27 & 4.1070 & .59715 & .11492 \\
& Male & 8 & 4.1042 & .53735 & .18998 \\
\hline
\end{tabular}

4.7 Students' understanding of using Edmodo app in learning paragraph writing- its benefits, challenges and suggestions

Having collected the data of questionnaire, the researcher interviewed 6 participants among the experimental group so as to gain insight into their understanding of using Edmodo for paragraph writing in their writing lessons, the benefits, the challenges as well as the future learning with the app. Due to the Covid19 pandemic, online interviews in Zoom were carried out to collect qualitative data. Afterward, the data were transcribed and analyzed

\subsubsection{The usefulness of the functions on Edmodo app}

In terms of the usefulness of the functions on Edmodo app, all of 6 participants, accounting for 100\%, agreed that Assignment is the most useful function, followed by Post function when they use Edmodo app for their writing learning.

"..... The function that I feel the most useful is the Assignment function. It helps me to submit writings so that I can complete a few writings to improve my skills even more." (Participant 1)

“... I think the Assignment is the most useful. For example, I am given the homework and I have a deadline for me to do it and I can get the correction from the teacher." (Participant 2)

"........ I find the useful function where homework is assigned to us. ...... listening lessons are posted for us so that we can practice listening on it instead of writing skill, then ......... we refine it. The sentence for the essay is better". (Participant 3).

"..........this is the Assignment function where I can do my homework and send it to the teacher. Then my writing can be graded and corrected. And I can know where I am wrong. I can do the assignments anytime, anywhere." (Participant 4).

“......... the submission function, it's convenient for me." (Participant 5).

"......the function I like is Post function and then it has a comment section so that the teacher can correct the students' mistakes with the grading part. I think it's very useful." (Participant 6)

However, each of them has differently found the least useful function of the app.

“... As for the most useless function, I think it's Messages because now, social networks are growing a lot, I feel that using messages in Edmodo is not very useful. "(Participant 1).

“..... sometimes when we want to click submit or click something, it shows many letters or many things for us to choose. It gets confused." (Participant 2).

“...And I don't like the corrections place very much because sometimes when we post it, it's quite difficult to see teacher's corrections on our posts, so sometimes we don't understand clearly how we can correct the mistakes." (Participant 3)

“.... that's the place where....to send assignments, for example, if I want to send my homework, I have to type in a password or an application, then insert it and then send it up. I can't type it directly. I don't find it useful. Ifeel it's too cumbersome." (Participant 4). 


\section{DOI: $\underline{10.51386 / 25815946 / \mathrm{ijsms}-\mathrm{v} 4 \mathrm{i} 6 \mathrm{p} 118}$}

\subsubsection{The enjoyment in using Edmodo app}

Two of them revealed that they enjoyed learning writing English paragraph with Edmodo app because they can submit the writing from anywhere and they can receive the teacher's remark effectively.

".... What I like the most is the one that shows more words to write and teacher can correct and give us points directly." (Participant 3).

“- Ah, my favorite part is the place where I can send my work to Ms. Then You can grade me, correct me, that's my favorite part." (Participant 4).

Two of them have been engaged to the topic writing through small activities/ quizzes on the app for example: listing new words ideas for the new topic, games, and listening parts.

“..... I like it when you post games or small snippets for us to practice so that it doesn't take too much time." (Participant 2)

“.... that is to submit assignments anytime, anywhere, then I can absorb a lot of information from the teacher to write a paragraph." (Participant 6)

\subsubsection{The difficulties in using Edmodo app}

Three of them, accounting for 50\%, have noticed that they often met some problems in using the app such as: internet connection, the display of the app, the spelling way during submitting.

"...Difficult problem, the biggest problem seems to be the connection when logging in, registering in the application. The second difficulty I think is the problem of connecting with Microsoft Word to be able to transfer. Ifeel it is quite complicated." (Participant 1)

"And what I don't like is that it often shows ads on the top. It's hard for us to find the posts you post."

(Participant 2)

"....... sometimes when I write or misspell, the computer will correct the words. However, when I post it, it will stick like that and it won't fix. sometimes when I want to look for a certain post, it's lost. I can't find the latest posts." (Participant 3)

Three of them have found no challenges in using the app.

"I think it's fine, no problems." (Participant 4)

“.... do you have any difficulty using Edmodo in learning to write your English passages? - No." (Participant 5)

"The thing I don't like the most is almost none." (Participant 6)

\subsubsection{The improvement of writing skill after using the app}

All of them have agreed that thanks to Edmodo, their English paragraph writing has improved, specially, the improvement of their grammar, word choice, coherence.

“... I completely agree that through this Edmodo application, I improved a very, very big part. Since using until now, writing skills as well as listening skills and so on about English have improved a lot."

(Participant 1).

“.... in my opinion, I have improved a lot in terms of grammar, and I also know more about vocabulary. When our teacher gave us a writing topic that we didn't know much about, we also had to find information, which also increased our information. Then teacher can also correct the mistakes and send them back for me to see and correct for other times." (Participant 2).

“... at first, my words used were quite simple for my essays because I often used familiar words, then gradually, I used new words that I learned in class in order to be able to refine the sentences. The text sounds better. The word is not repeated anymore." (Participant 3 ) 


\section{DOI: $\underline{10.51386 / 25815946 / \text { ijsms-v4i6p118 }}$}

Volume: 4 Issue: 6

November to December 2021

https://www.ijsmsjournal.org

“... I used to write very little, but since using Edmodo, it has suggested me many words and grammar, so I will write better and paragraphs are more concise and complete." (Participant 4)

".... there is a lot of improvement. I know more vocabulary through the vocabulary lists teacher sent."

(Participant 6)

"I have improved in grammar and vocabulary because teacher corrected my grammar and vocabulary mistakes for me." (Participant 5)

Nevertheless, one of them noticed that he has repeated certain words in a paragraph.

“.... a.. about how to write sentences, I see that I repeat too many words and how to correct mistakes every time." (Participant 4)

One of them recognized that the connection between the sentences in a paragraph hasn't improved perfectly.

“.. I haven't made any progress in putting sentences together, it's still not very coherent.”

(Participant 5)

\subsubsection{The future learning of writing with the app}

All of them agreed that Edmodo app is very useful in their English paragraph writing in many ways and they are using this app for their writing learning in the future.

“....... in the future, I will definitely use this application a lot because I find it completely useful for us."

(Participant 1)

"According to me, I will use it for a long time because it helps me a lot in my study, in my writing process."

“....... I really like to use Edmodo for writing, specifically I apply it to the exams such as national high school and university exams...." (Participant 4)

“...... it's very convenient for me and it's not too difficult for me. ” (Participant 5)

In conclusion, the participants understood the benefits and barriers that Edmodo offers. Especially, they all found that they are interested in using the Edmodo app in their paragraph writing lessons.

\section{DISCUSSION}

The current study aimed at investigating the implementation of Edmodo app to EFL students' paragraph writing. Furthermore, the study sought to examine learners' attitude towards the use of Edmodo in their writing lessons. The findings of the study indicated that there are both similarities and differences between this study's findings and those of the previous related studies.

The results of the present study are in line with Duwila \& Khusaini's (2019) investigation. Duwila \& Khusaini (2019) explored that the use of Edmodo had a significant effect on EFL students' paragraph writing performance. The results of the present study are in confruence with the findings of Al-naibi, AL-Jabari, \& Al Kalbani (2018), Ma'azi \& Janfeshan (2018) . They found that after the treatment of learning paragraph writing with the Edmodo app, there was a statistically significant improvement in students' writing performance. In a similar vein, Noviana et al. (2015) found the effectiveness of Edmodo in writing a narrative text in senior high school. Soliman (2021) and Maryam Safdari (2021) found that Edmodo led to the improvement of writing skills.

The findings of the study are in line with the findings of Al-Said (2015),Mali (2014), Monalisa \& Havid Ardib (2013) and Godwin-Jones (2008). They found the same results in their studies that students had positive attitudes towards the use of Edmodo in their paragraph writing learning. Learners' perceptions towards Edmodo were highly favorable. Another justification for the findings of the current study could be the features of giving feedback. The results of the study concluded that Edmodo including online feedback is used with joyfulness by students. Gender difference in writing achievement has been debated among researchers. This present study supported the findings that there is no significant difference between female learners and male learners in achieving paragraph writing performance.

In terms of the integration of internet-based learning platform, the findings of this study concerning Edmodo as a useful learning platform are also in accordance with Charoenwet \& Christensen (2016). They 


\section{DOI: $\underline{10.51386 / 25815946 / \text { ijsms-v4i6p118 }}$}

found the effects of integrating Edmodo, an internet-based learning management, on students' writing proficiency. Kongchan (2008) found that Edmodo is a marvelous learning platform and its ease of use. As Gay \& Sofyan (2017) maintained, Edmodo enhances cooperation and collaboration among teachers and students. Similarly, the results of this study are in congruence with Kandappan Balasubramaniana, Jaykumar Vb \& ASchool (2014) and Purnawarman et al. (2016). They found that the utilizing of Edmodo in students' paragraph writing lessons motivates their engagement and responsibility in learning writing.

It cannot be denied that there is a variety of research worldwide on the effectiveness of Edmodo app on learners' paragraph writing. In fact, the studies on this prospect are considerably limited in the setting of Vietnam, especially at a high school in Soc Trang province. Therefore, Edmodo app is anticipated to make some contributions to students' paragraph writing learning to some extent.

All in all, the results of the pretest and posttest showed that Edmodo significantly impacted on students' writing performance. The results from the questionnaire and interview further revealed that learners held positive attitudes towards the use of Edmodo in their writing classrooms. Particularly, students positively perceived that Edmodo was a useful social learning platform in improving their paragraph writing performance.

\section{CONCLUSIONS}

The present study was carried out to examine the impacts of Edmodo app on EFL students' paragraph writing and investigate their attitudes towards using Edmodo in learning English writing. The findings from the writing tests first showed an improvement in EFL students' paragraph writing performance after they had experienced Edmodo. Regarding EFL students' attitude, the data from the questionnaire and interviews revealed that EFL students hold high positive attitudes towards using Edmodo in learning English writing. In light of these findings, some pedagogical implementations are drawn.

For authorities, those findings will be considered as a source of reference for educational administrators and school leaders to design appropriate online course as a high school graduation requirement in their curriculum.

For teacher, the understanding of the impacts of Edmodo app on EFL students' paragraph writing performance will assist teachers have a better view of using Edmodo to teach English writing. In a virtual learning environment, teachers could take advantage of a variety of updated materials without cost, a lot of diverse lessons and a collaborative and cooperative learning mood. The results indicated that teachers could employ activities on Edmodo app as supplementary practice for students, which creates a great deal of active and fruitful courses. Teachers should give students maximum opportunities to practice English writing. Therefore, it is necessary to show the teacher's wishes about students' development, improvement and changes through asking them revise their writing based on the feedback given through Edmodo app for the better. The findings of the current study also revealed that Edmodo promoted collaboration. It is suggested that teachers could take this feature of Edmodo for granted and instruct learners to work as collaboratively as possible. Needless to say, learners need to be rewarded, praised and motivated for what they have done well during the process so that they feel their work and efforts are appreciated. Teachers could mingle the teaching methods to motivate students' engagement, responsibility and spirit of learning English, especially writing English among students. The implication of Edmodo could expand the learning environment beyond the classroom context. It is suggested that teachers implement Edmodo app as technology application for teaching and learning writing.

For students, this research is hoped to raise awareness of students of using Edmodo-an educational platform in learning English writing. The research also hoped to gain insight into the implementation of social networking sites, particularly Edmodo to assist students to acquire writing successfully. In addition, as the results of the study shows, students are interested in the application of Edmodo as an educational tool with a variety of activities related to the aims of the lessons. Indeed, the findings of the present study showed EFL students' enjoyment when practicing writing English integrating Edmodo app. It is recommended that the students who have low English skills, low motivation, low self-esteem, and debilitating anxiety should attend the classes in which Edmodo is integrated to enhance their writing performance. Additionally, learners should know about the drawbacks of being inaccuracy so that they might make the use of teacher feedback on Edmodo app as a habit to do. 


\section{DOI: $\underline{10.51386 / 25815946 / \mathrm{ijsms}-\mathrm{v} 4 \mathrm{i} 6 \mathrm{p} 118}$}

Volume: 4 Issue: 6

November to December 2021

https://www.ijsmsjournal.org

\section{About the Authors}

Yen Kieu Ngoc Lieu is currently an MA student at Can Tho University, Vietnam. Her research interests consist of writing skills and strategies, and teaching methodology. She also indulges in enhancing the learning experience and applying innovative approaches for EFL students.

Hoang Yen Phuong is currently an Associate Professor at the School of Foreign Languages, Can Tho University, Vietnam. She conducts studies on language teaching approaches, students'learning autonomy, selfregulated learning strategies and teachers' professional development. She published articles in different journals and is the editor of one book on formative assessment in language teaching.

\section{References}

[1] A. Muhtia, S. Suparno, \& S. S. (2019). Taking a Closer Look At Blended Learning Activities in a (Vol. 6, pp. 1-17). https://eric.ed.gov/?q=paragraph+writing \&id=EJ1248483

[2] Al-naibi, I;AL-Jabari, M; Al Kalbani, I. (2018). Promoting Students 'Paragraph Writing Using EDMODO : An Action Research. In TOJET: The Turkish Online Journal of Educational Technology (Vol. 17, Issue 1, pp. 130-143).

[3] Al-Said, K. M. (2015). Students' perceptions of edmodo and mobile learning and their real barriers towards them. In Turkish Online Journal of Educational Technology (Vol. 14, Issue 2, pp. 167-180).

[4] Charoenwet, S., \& Christensen, A. (2016). The effect of Edmodo learning network on students' perception, self-regulated learning behaviors and learning performance. In IMSCI 2016 - 10th International Multi-Conference on Society, Cybernetics and Informatics, Proceedings (pp. 297-300).

[5] Chuttur, M. (2009). Overview of the Technology Acceptance Model: Origins, Developments and Future Directions. In Sprouts: Working Papers on Information Systems (Vol. 9, Issue 37, pp. 1-23). https://doi.org/10.1021/jf001443p

[6] Cumming, A. (2002). Assessing L2 writing: Alternative constructs and ethical dilemmas. In Assessing Writing (Vol. 8, Issue 2, pp. 73-83). https://doi.org/10.1016/S1075-2935(02)00047-8

[7] Duncan, M. (2007). Whatever happened to the paragraph? College English, 69(5), 470-495.

[8] Duwila, S., \& Khusaini, T. (2019). Pedagogical strategy of writing paragraph using Edmodo to enhance writing skill for EFL students. In Journal of English Language .... http://eprints.uwp.ac.id/id/eprint/542/

[9] Eagly, A. H., Chen, S., Chaiken, S., \& Shaw-Barnes, K. (1999). The Impact of Attitudes on Memory: An Affair to Remember. In Psychological Bulletin (Vol. 125, Issue 1, pp. 64-89). https://doi.org/10.1037/0033-2909.125.1.64

[10] Gay, E., \& Sofyan, N. (2017). The_Effectiveness_of_Using_Edmodo_in_Enh.pdf(pp. 1-11). https://doi.org/ISSN: 2502-6909

[11] Godwin-Jones, R. (2008). Emerging technologies web-writing 2.0: Enabling, documenting, and assessing writing online. In Language Learning and Technology (Vol. 12, Issue 2, pp. 7-13).

[12] Harklau, L. (2002). The role of writing in classroom second language acquisition. Journal of Second Language Writing, 11(4), 329 350. https://doi.org/10.1016/S1060-3743(02)00091-7

[13] Hobsbawm, E. (2007). Students' Perceptions on the Effectiveness of the Use of Edmodo as a Supplementary Tool for Learning. In DLSU Research Congress (pp. 6-11).

[14] Jain, V. (2014). 3D Model of Attitude. In International Journal of Advanced Research in Management and Social Sciences (Vol. 3, Issue 3, pp. 1-12). http://www.garph.co.uk/IJARMSS/Mar2014/1.pdf

[15] Kandappan Balasubramaniana, Jaykumar Vb, L. N. F., \& ASchool. (2014). Srudent preference towards the use of Edmodo.pdf (pp. 417-421).

[16] Kongchan, C. (2008). How a Non-Digital-Native Teacher Makes Use of Edmodo. In Internacional Conference "ICT for Language Learning."

[17] Lombana, C. (2002). Some Issues for the Teaching of Writing. In Profile Issues in Teachers` Professional Development (Vol. 3, Issue 1, pp. 44-51).

[18] Ma'azi, H., \& Janfeshan, K. (2018). The effect of Edmodo social learning network on Iranian EFL learners writing skill. In Cogent Education (Vol. 5, Issue 1, pp. 1-17). https://doi.org/10.1080/2331186X.2018.1536312

[19] Mali, Y. (2014). Edmodo As a Virtual Learning Environment In Academic Writing Class. In Proceeding of Ithe Third International Seminar on English Languge and Teaching (pp. 527-533). http://ejournal.unp.ac.id/index.php/selt/article/view/6898 


\section{DOI: $\underline{10.51386 / 25815946 / \mathrm{ijsms}-\mathrm{v} 4 \mathrm{i} 6 \mathrm{p} 118}$}

Volume: 4 Issue: 6

[20] Maryam Safdari. (2021). Safdari2021.pdf(pp. 343-361).

[21] Monalisa, \& Havid Ardi. (2013). Using Edmodo Educational Social Network In Teaching English For High School Sudents. In Journal of English Language Teaching (Vol. $2, \quad$ Issue $1, \quad$ pp. 220-225).

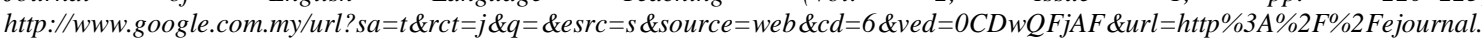
unp.ac.id\%2Findex.php\%2Fjelt\%2Farticle\%2Fdownload\%2F2609\%2F2209\&ei=cs4PVJ7gG4ySuASHt4LAAw\&usg=AFQjCNGkN MtQOT2ypNQZf_-E1rP-nMIRsg \&bvm=bv.74649129,d.c2

[22] Noviana, O., Rufinus, A., \& Bunau, E. (2015). the Effective Use of Edmodo in Writing a Narrative Text in Senior High School. In Jurnal Pendidikan dan Pembelajaran Untan (Vol. 4, Issue 11).

[23] Ozag, D., \& Duguma, B. (2004). The relationship between cognitive processes and perceived usefulness: An extension of TAM2. In Proceedings of 23rd Annual Organizational Systems Research Association Conference (pp. 1-24).

[24] Prananda, Y. A. (2016). Students' Ability in Writing Paragraphs Using Structure of The Paragraph in Argumentative Essay By The Sixth Semester of English Study Program of Muhammadiyah University of Bengkulu. In Linguists : Journal Of Linguistics and Language Teaching (Vol. 3, Issue 1).

[25] Purnawarman, P., Susilawati, \& Sundayana, W. (2016). The use of Edmodo in teaching writing in a blended learning setting. In Indonesian Journal of Applied Linguistics (Vol. 5, Issue 2, pp. 242-252). https://doi.org/10.17509/ijal.v5i2.1348

[26] Rafidah, S., Al-Kathiri, F., \& MUHAMMAD YOGI. (2014). No 主観的健康感を中心とした在宅高齢者における健康関連指標 に関する共分散 構造分析 Title. In English Language Teaching (Vol. 39, Issue 1, pp. 1-24). http://dx.doi.org/10.1016/j.biochi.2015.03.025\%0Ahttp://dx.doi.org/10.1038/nature10402\%0Ahttp://dx.doi.org/10.1038/nature21059 \%0Ahttp://journal.stainkudus.ac.id/index.php/equilibrium/article/view/1268/1127\%0Ahttp://dx.doi.org/10.1038/nrmicro2577\%0Ahtt $p: / /$

[27] Rahmalia, I. (2016). Students' Linguistic Competence in Essay Writing. Al-Ta Lim Journal, $23(3), 241-248$. https://doi.org/10.15548/jt.v23i3.241

[28] Rozalinda, R., Rozimela, Y., \& Anwar, D. (2020). The Ability of English Department Students in Writing Cause and Effect Essay in Universitas Negeri Padang. 411(Icoelt 2019), 402-407. https://doi.org/10.2991/assehr.k.200306.067

[29] Sari, A. K. (2018). An analysis of problems faced by first year students of STKIP Muhammadiyah Muaro Bungo in writing cause and effect essay. Jurnal Muara Pendidikan, 3(2), 191-199.

[30] Saud, I. W. (2015). The Use of Cohesive Device in Writing Cause and Effect Essay Indah Wardaty Saud Faculty of Cultural Science University of Muhammadiyah Gorontalo. 6(1), 88-98.

[31] Soliman, A. T. A. (2021). Using Edmodo in teaching English to develop secondary stage stude.pdf (pp. 17-38). Journal of Faculty of Education Assiut University. https://digitalcommons.aaru.edu.jo/jfe_au/vol37/iss3/11

[32] Thongmak, M. (2013). Social Network System in Classroom: Antecedents of Edmodo (C) Adoption. In Journal of e-Learning and Higher Education (pp. 1-15). https://doi.org/10.5171/2013.657749

[33] Ulfa, S. M., Susanto, S., \& Purwati, O. (2020). Beyond the Application of Edmodo in Classroom: Students'Perceptions and Their Barriers in the Process of Utilizing It in .... In ... Pendidikan Bahasa Inggris.

[34] van Harreveld, F., Nohlen, H. U., \& Schneider, I. K. (2015). The ABC of Ambivalence (pp. 285-324). https://doi.org/10.1016/bs.aesp.2015.01.002

[35] Van, H. Van. (2018). Moet'S Three Pilot English Language Communicational Curricula for Schools in Vietnam: Rationale, Design and Implementation. VNU Journal of Foreign Studies, 34(2). https://doi.org/10.25073/2525-2445/vnufs.4258

[36] Wali, O., \& Madani, A. Q. (2020). The Importance of Paragraph Writing: An Introduction. In Organization (Vol. 3, Issue 07, pp. 4450). www.ijlrhss.com

[37] Wicker, A. W. (1969). Attitudes versus Actions: The Relationship of Verbal and Overt Behavioral Responses to Attitude Objects. In Journal of Social Issues (Vol. 25, Issue 4, pp. 41-78). https://doi.org/10.1111/j.1540-4560.1969.tb00619.x

[38] Yi, J. (2009). Defining Writing Ability for Classroom Writing Assessment in High Schools (Vol. 13, Issue 1, pp. 53-69). 